\title{
PELIS Forestry Programme as a Strategy for Increasing Forest Cover and Improving Community Livelihoods: Case of Malava Forest, Western Kenya
}

\author{
Agevi Humphrey, *, Mwendwa Kaleb Adamba ${ }^{2}$, Koros Hillary ${ }^{1}$, Mulinya Carolyne ${ }^{3}$, \\ Kawawa Rashid Calvince ${ }^{1}$, Kimutai Donald Kipruto ${ }^{4}$, WabusyaMoses ${ }^{5}$, Khanyufu Mercy ${ }^{1}$, \\ Jawuoro Stanely ${ }^{6}$ \\ ${ }^{1}$ Department of Biological Sciences, Masinde Muliro University of Science and Technology (MMUST), Kakamega, Kenya \\ ${ }^{2}$ Centre for Kakamega Tropical Forest Studies (CEKATFOS), Masinde Muliro University of Science and Technology (MMUST),Kakamega, \\ Kenya \\ ${ }^{3}$ Department of Geography, Masinde Muliro University of Science and Technology (MMUST), Kakamega, Kenya \\ ${ }^{4}$ Graduate School of Environmental Earth Science, Hokkaido University, Sapporo, Japan \\ ${ }^{5}$ Department of Biological Sciences, Moi University, Eldoret, Kenya \\ ${ }^{6}$ Department of Land Resource Management and Agricultural Technology (LARMAT), University of Nairobi, Nairobi, Kenya
}

Email address:

hagevi@mmust.ac.ke (A. Humphrey)

${ }^{*}$ Corresponding author

To cite this article:

Agevi Humphrey, Mwendwa Kaleb Adamba, Koros Hillary, Mulinya Carolyne, Kawawa Rashid Calvince, Kimutai Donald Kipkorir, Wabusya Moses, Khanyufu Mercy,JawuoroStanely. PELIS Forestry Programme as a Strategy for Increasing Forest Cover and Improving Community Livelihoods: Case of Malava Forest, Western Kenya. American Journal of Agriculture and Forestry.

Vol. 4, No. 5, 2016, pp. 128-135. doi: 10.11648/j.ajaf.20160405.13

Received: August 14, 2016; Accepted: August 26, 2016; Published: October 9, 2016

\begin{abstract}
Plantation Establishment and Livelihood Improvement Scheme (PELIS) is a scheme introduced after enactment of the Forest Act, 2005. It is a governance scheme by Kenya Forest Service (KFS) to help increase forest cover and restore degraded forests in the country. Forest adjacent communities (FAC) benefit from the scheme where they allocated plots upon which they plant seedlings, take care of them till the area form a closed canopy while they practise agriculture on the farms. This research sought to determine the extent to which PELIS has helped increase forest cover through plantations and decreased forest dependency. Both quantitative and qualitative data was used. It also sought to determine how the programme has helped improve community livelihoods.Cloud-free satellite images of 2001 to 2016 were selected for the study. The spectral bands 1-5 and 7 were chosen for Landsat 7 while bands $2-7$ were used for Landsat 8 . These were used to analyse forest cover and forest cover change for the period 2001 to 2016. The 2001 satellite image was used to analyse forest cover before PELIS and the 2016 image was utilized to analyse forest cover during the PELIS programme. Open and closed ended questionnaires, interviews and discussions were used to determine benefits of PELIS and how it has helped improve their livelihoods. It was found that forest cover experienced a positive increase from 366.9 ha in 2001 to 481.4 ha in 2016, an increase of $114 \mathrm{ha}(51 \%)$. This was occasioned by increased areas under plantations under the PELIS programme. The respondents admitted that they get food produce for their families like maize, beans, and potatoes. They also sell some of the produce and realize income of between Kshs.5, 000-15,000 annually from the parcel of land they are allocated. $90 \%$ of the respondents did agree that the programme has helped decrease forest dependency as most used to go to the forest to get timber and firewood to sell to get some cash. The success of this programme in Malava could be emulated in other forests in the country that will lead to an increase in forest cover and help improve their livelihoods.
\end{abstract}

Keywords: PELIS Programme, Forest Cover, Forest Cover Change, Community Livelihoods 


\section{Introduction}

Forests form part of peoples' livelihoods especially the Forest Adjacent Communities (FAC) [1]. These are people who stay at a radius of $10 \mathrm{~km}$ from the forest edge [2]. Forests are valuable natural endowment and especially to our country that must be sustainably managed for present and future generations. They offer a range of benefits and opportunities for local and national economic development. These include improved livelihoods, provision of environmental goods and services such as watershed protection, water regulation, water purification, waste treatment and water pollution sinks [3]. Other services provided include erosion control, natural hazard and disease regulation, habitat for a great diversity of fauna and carbon sequestration $[4,5,1]$. The increasing human population and overdependence of forest products has resulted to decline in forest cover[6].Globally forest-cover has experienced a significant decline, going from about 6 billion ha to approximately 4 billion ha in the last millennia[7]. This has however been reversed and the decline began to show decreasing trend, from $0.2 \%$ between 1990 and 2000 to $0.12 \%$ and $0.14 \%$ in the periods from 2000 to 2005 and 2005 to 2010 , respectively [8]. This has been as a result of reforms in forest policies aimed at meeting the demands of the growing population and at the same time conserve the forests sustainably. In Kenya, the forest sector has experienced poor performance in the past.Improving forest governance has been an implicit objective in forest sector reforms over the past ten years as a strategy to help increase the forest cover. Currently forest cover is at $6.99 \%$ of the total land area. This is still below the constitutional requirement [3] and the recommended threshold by the United Nations [8]. The Forests Act (2005) introduced participatory forest management (PFM), through the engagement of local communities, and the promotion of the private sector investment in gazetted forest reserves. This was accompanied by concomitant institutional and organization change, notably the establishment of the Kenya Forest Service (KFS), formerly the forest department (FD) and the formation of Community Forest Associations(CFA) [9, 3].PFM is a concept that has been used to manage forest resources in developing countries. These forest adjacent communities have a stake in the management of forest resources including policy formulation processes [2].A major reform that was introduced was the rebranding of the shamba system into Plantation Establishment and Livelihood Improvement Scheme (PELIS) [10, 11]. This is a system the Kenya Forest Service (KFS) introduced to allow Forest Adjacent Community (FAC), through Community Forest Associations (CFAs) the right to cultivate agricultural crops particularly the local population's staple foods and so serves to satisfy the farmer's quest for arable land. The cultivation is done during the early stages of forest plantation establishment or re-establishment in degraded areas of the forest. The programme is affirmatively geared to assist and/or benefit the most vulnerable groups of the society and are implemented by the Community Forest Association (CFA's), under the participatory forest management PFM and PELIS guidelines (Forest Act 2005) envisaged to deliver benefits such as; boost conservation efforts, improve food security for the forest adjacent communities (FACs) and the country at large. In addition it is aimed at increasing incomes and generates revenue to the Treasury from the land rent of the plots. This is through the savings by the KFS realized in establishing the forests. Kakamega Forest one of the tropical forests in Kenya is managed by two bodies [12]. The Kenya wildlife Service (KWS) manages the reserve part of the forest and Kenya Forest Service (KFS) manages the southern part of the forest and Malava forest. Malava Forest is a fragment of Kakamega Forest [13]. In the area managed by KFS, the community is mandated to co-manage the forest through their established CFAs. This is the area that PELIS programme has also been established especially in areas that initially were forested but there was clear cutting of trees. KFS has therefore initiated this scheme as a measure to help restore the area with trees. This research therefore sought to a.) determine Malava Forest cover change from 2001 to 2016, a) determine the extent of PELIS programme contribution around Malava Forest in increasing forest/Land cover; b) relate PELIS Programme to forest dependency on Malava Forest and c) determine effect of the PELIS programme on people's livelihoods around the forest. These findings will play a key role and especially to the KFS, CFAs in strengthening the programme around the forest. The results can also be emulated in other natural forests in Kenya and other parts of the world.

\section{Study Area}

The study was conducted around Malava Forest, a fragment of Kakamega Forest (Althof, 2005).The forest is located in central Kabras division, Malava sub-county in Kakamega County. The forest is situated approximately $25 \mathrm{~km}$ North of Kakamega Town along Kakamega-Webuye road. It lies at latitude $0^{\circ} 28^{\prime} 54^{\prime \prime} \mathrm{N}$ to $0^{\circ} 29^{\prime} 44^{\prime \prime} \mathrm{N}$ and longitudes $34^{\circ} 50^{\prime} 15^{\prime \prime} \mathrm{E}$ to $34^{\circ} 52^{\prime} 26^{\prime \prime} \mathrm{E}$ (Figure1). The forestis a state forest managed by Kenya Forest Service (KFS) having been gazetted under proclamation no.14 of $13^{\text {th }}$ February, 1933. It is part of Kakamega Forest Ecosystem together with Kakamega, Kibiri, Bunyala and Kisere Forests. It covers an area of 717.3ha including 4.5 ha for Malava Girls' High School to the south of the forest. It is divided into three administrative beats namely Makhabuye, Shitirira and Pukoye for purposes of patrols by the forest rangers. Malava Forest being part of the larger Kakamega Forest Ecosystem (KFE) was originally a natural forest mainly composed of high indigenous trees like Olea capensis, Diospyros abyssinica, Maesopsis eminii, croton macrostachyus and Prunus africana. However deforestation and pressure from the surrounding communities resulted to clearing of the natural vegetation on larger parts of the forest and replanting with exotic commercial trees species like Cupressus lusitanica, Pinus patula, Eucalyptus saligna and Bischofia javanica. 


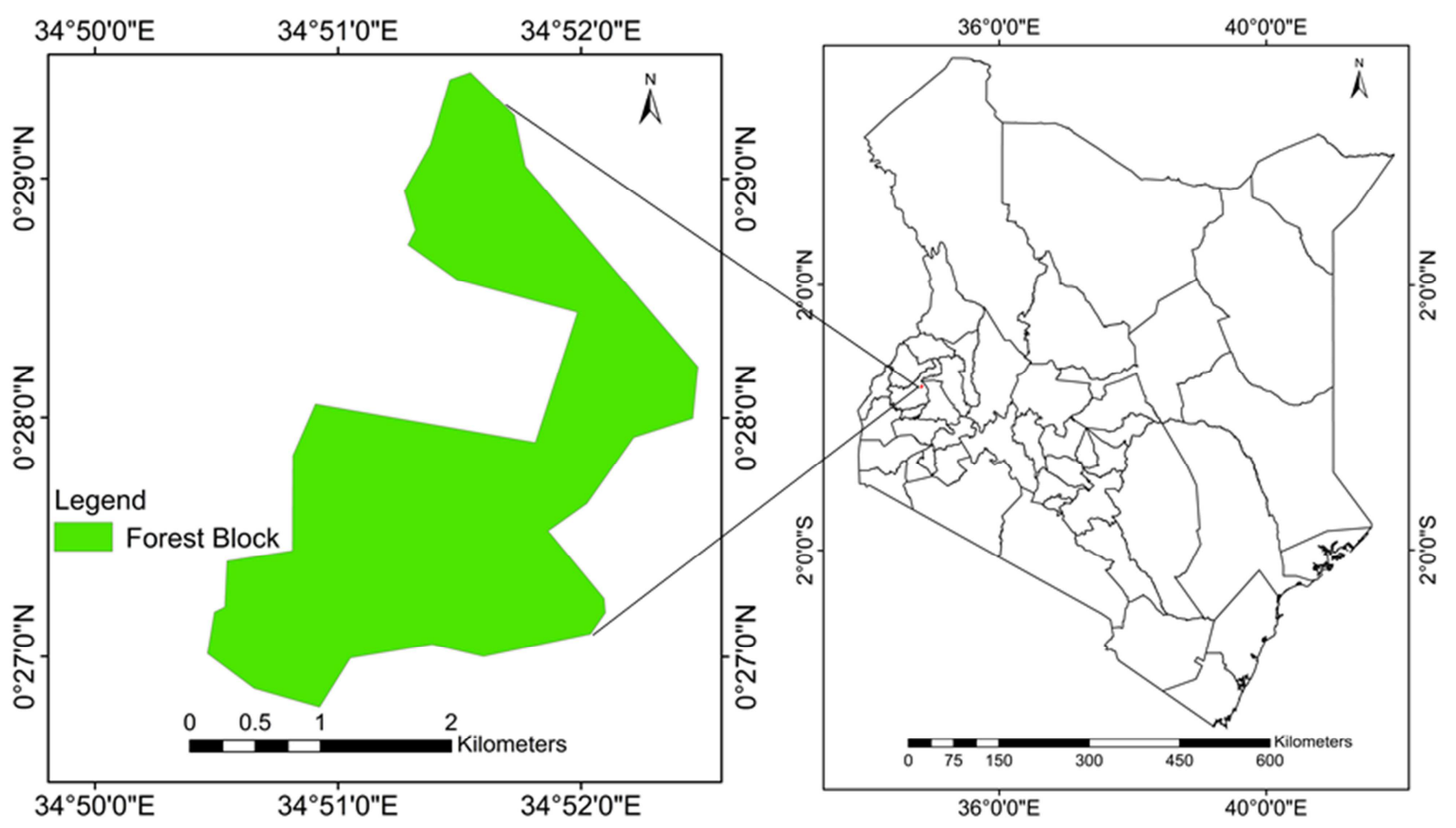

Figure 1. Map of the study area (Source: Author).

\section{Sampling and Data Collection}

\subsection{Determination of Forest Cover}

A combination of both qualitative and quantitative data was used to help determine the status of forest cover change which PELIS is one of the factors that has contributed to the same in addition to natural restoration. Secondary data on land cover change detection was collected by downloading Landsat images. Cloud-free satellite images of 2001 to 2016 were selected for the study. The 2001 satellite image was used to analyse forest cover before PELIS and the 2016 image was utilized to analyse forest cover during the PELIS programme. The images were obtained from the United States Geological Survey (USGS) Global Visualization Viewer website (www.glovis.usgs.gov).The Kenya forest-cover shape files were obtained from the Survey of Kenya and KFS, respectively. The spectral bands of the selected Landsat images were individually imported to ArcGIS 10.2. The spectral bands $1-5$ and 7 were chosen for Landsat 7 while bands 2-7 were used for Landsat 8 . These selected spectral bands were co-registered to Universal Transverse Mercator (UTM) zone $36 \mathrm{~N}$. The acquired forest shape files were used to clip out the study area from the pre-processed Landsat imageries. To aid in identification of dominant land-cover types, unsupervised classification was performed in ArcGIS 10.2. Using the results of unsupervised classification, Google Earth imagery, and our familiarity of the study area, three land-cover classes (forest (closed forest and open forest), grassland, and barren land) were identified for Landsat images from 2001 to 2016 (Table 1).
Table 1. Description of the land cover types identified.

\begin{tabular}{ll}
\hline Land cover & Description \\
\hline Forest land & $\begin{array}{l}\text { Densely vegetated areas characterised by overlapping tree } \\
\text { canopies }\end{array}$ \\
Grassland & $\begin{array}{l}\text { Areas covered with grass } \\
\text { Areas without vegetation cover-e.g., rocky and bare } \\
\text { Barren land }\end{array}$ \\
\hline
\end{tabular}

\subsection{Social Survey}

Purposive sampling was used to select famers adjacent to the forest and who benefit from the PELIS programme. This method of sampling is preferred for household surveys and interviews in relation to forest resources and utilisation[14]. Farmers were identified with the help of Kenya Forest Service (KFS) officers and chairman of Malava Forest Association (MAFOA). Observations, interviews and openended and closed-endedquestionnaires were employed in data collection. Observation was simply used to determine how community is involved in the PELIS programme. Interviews targeted the forest rangers, officials in charge of the PELIS programme and KFS officials' in-charge of Malava Forest and who helped determined the procedure for identifying farmers for the PELIS programme. The interviews were used to gather information on the likely impact of the programme on the forest cover and how it has greatly helped improve livelihoods of the Forest Adjacent Communities (FAC). This targeted KFS officers and officials of the forest association. Open-ended and closed-ended questionnaires targeted 200 farmers around the forest to determine how they have benefitedand likely challenges from the programme. Stratified random sampling technique was used to select 
farmers identified with the help of chairman Malava community forest association where each division around the forest was taken as a stratum and households within $5 \mathrm{~km}$ from the forest boundary were administered questionnaires at a systematic random sample rate of every 10th household.

\section{Data Analysis}

Data entry and management was done by use of Microsoft excell programme. Data was analyzed using several softwares which included ArcGIS 10.2, image processing software ERDAS 2010, Garmin software for hot linking photos with GPS points and Microsoft excel. Summaries of data were presented in tables, bar graphs and chart. Data presentation was done by use of frequency distribution tables, bar graphs and pie-charts. Kappa accuracy was calculated as $=[($ Total $\times$ Sum of correctly identified $)-$ Sum of the entire row total $\times$ column total)]/[Total squared- Sum of the entire row total $\times$ column total)] [15].

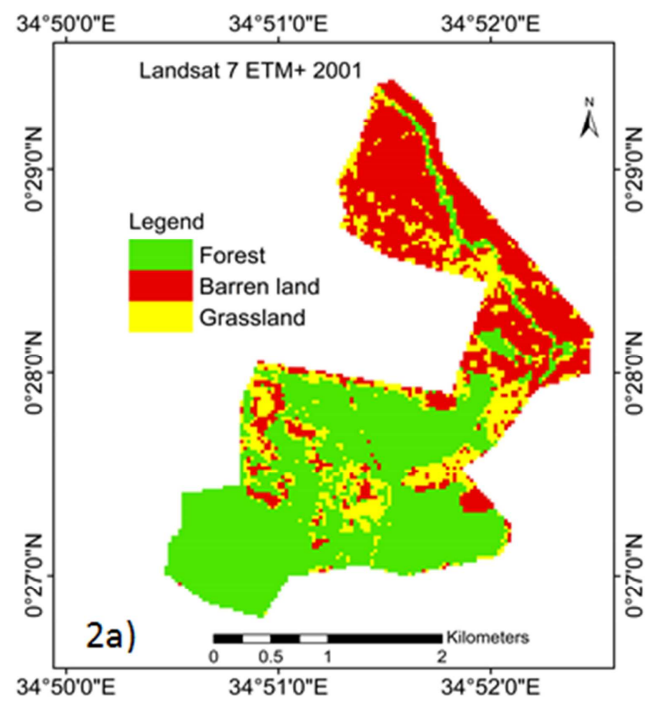

\section{Results}

\subsection{Land Use and Land Cover Change}

Forest remained the dominant land type in the period under investigation (Figure 2). However there was change in forest cover from the year 2001 to 2016. The forest cover experienced a positive increase from the initial 366.9ha in 2001 toabout $481.4 \mathrm{ha}$; thus marking a significant increase of 114.5ha (23.8\%). Barren land and grasslands represents areas currently under crop cultivation courtesy of PELIS programme. In some areas especially the margins and areas cleared felled of trees was done decreased in size. Barren land decreased from 227.3ha in 2001 to 220.8ha in 2016. Alsograssland showed a decreasing trend from 123.1 ha in 2001 to 15.1 ha in 2016 (Table 2). The decrease in barren land and grassland and the subsequent increase in forest cover were attributed to increased reforestation programmes and natural regeneration.

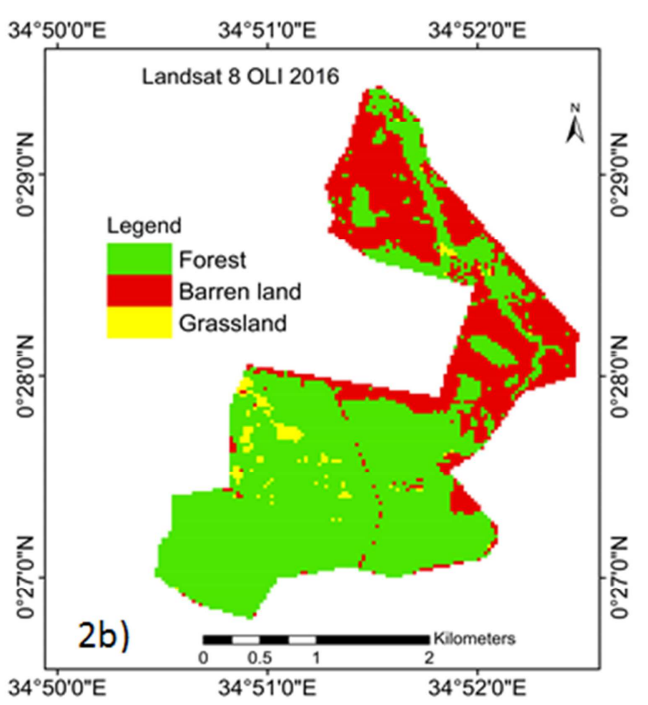

Figure 2. Land cover maps for Malava forest in; 2a) 2001 and 2b) 2016

Table 2. Area of each land cover type in hectares from 2001 to 2016

\begin{tabular}{lllll}
\hline \multirow{2}{*}{$\begin{array}{l}\text { Land cover } \\
\text { type }\end{array}$} & $\mathbf{2 0 0 1}$ & $\mathbf{2 0 1 6}$ \\
\cline { 2 - 5 } & Area (ha) & $\mathbf{\%}$ & Area (ha) & $\mathbf{\%}$ \\
\hline Forest & 366.9 & 51.2 & 481.4 & 67.1 \\
Barren land & 227.3 & 31.7 & 220.8 & 30.8 \\
Grass land & 123.1 & 17.1 & 15.1 & 2.1 \\
Total (ha) & 717.3 & 100 & 717.3 & 100 \\
\hline
\end{tabular}

In determination of forest change as one of the land cover, it was found out that forest land was the one that increased the most $(51 \%)$ as shown in (Table 3$)$. This was occasioned by increased areas under plantations which are areas under PELIS programme. They are indicated as change from barren/non-forest to forest lands and majority are at the margin areas (Figure 3).

Barren land/non-forest land and grasslands areas decreased in size as forest was recover ring itself through regeneration or through human assisted activities like tree planting.Barren land decreased from 227 ha to 176.3 ha while grassland area decreased from 123.1 ha to 52 ha.

Table 3. Change detection in land cover from 2001 to 2016

\begin{tabular}{|c|c|c|c|c|c|c|c|c|}
\hline \multicolumn{9}{|l|}{2016} \\
\hline \multirow{2}{*}{ Land-cover types } & \multicolumn{2}{|l|}{ forest } & \multicolumn{2}{|c|}{ Barren land } & \multicolumn{2}{|c|}{ Grass land } & \multicolumn{2}{|l|}{ Totals } \\
\hline & ha & $\%$ & ha & $\%$ & ha & $\%$ & ha & $\%$ \\
\hline forest & 352.8 & 49.2 & 12.7 & 1.8 & 1.4 & 0.2 & 366.9 & 51.2 \\
\hline Barren land & 65.0 & 9.1 & 156.1 & 21.8 & 6.2 & 0.9 & 227.3 & 31.7 \\
\hline Grass land & 63.6 & 8.9 & 7.5 & 1.0 & 52.0 & 7.2 & 123.1 & 17.2 \\
\hline Totals & 481.4 & 67.1 & 176.3 & 24.6 & 59.6 & 8.3 & 717.3 & 100 \\
\hline
\end{tabular}




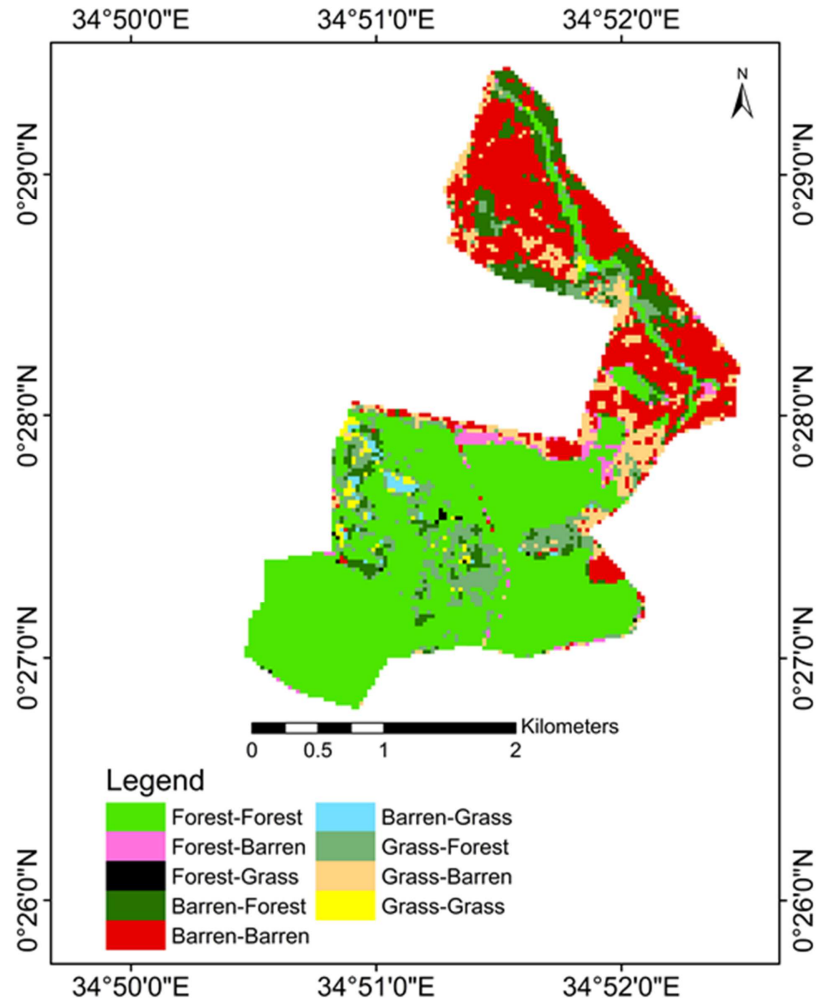

Figure 3. Change in land cover from 2001 to 2016.

The overall accuracy for the 2016 Landsat 8 classified image is shown in Table 4. The overall accuracy of the data was 93\%. In addition, Kappa for the 2016 Landsat 8 classified image (Congalton,1991) gave an accuracy of $90 \%$.

Table 4. Confusion matrix accuracy

\begin{tabular}{llllll}
\hline & Reference Data & & & & \\
\hline \multirow{4}{*}{$\begin{array}{l}\text { Classifie } \\
\text { dImage }\end{array}$} & forest & $\begin{array}{l}\text { Barren } \\
\text { land }\end{array}$ & $\begin{array}{l}\text { Grass } \\
\text { land }\end{array}$ & $\begin{array}{l}\text { RowsTo } \\
\text { tal }\end{array}$ \\
\cline { 2 - 6 } & forest & 31 & 0 & 0 & 31 \\
& Barren land & 1 & 31 & 0 & 32 \\
& Grass land & 3 & 2 & 20 & 25 \\
& Column Total & 35 & 33 & 20 & 88 \\
\hline
\end{tabular}

\subsection{Social Survey}

Table 5. A table showing the occupation of the respondents

\begin{tabular}{llll}
\hline S/N & Occupation & Percentage (\%) & frequency \\
\hline 1. & Farming & 50 & 100 \\
2. & Self employed & 25 & 50 \\
3. & Formal employment & 20 & 40 \\
4. & Not employed & 5 & 10 \\
\hline
\end{tabular}

The total respondents who formed the subject of research comprised of 53\% (106) males and 47\% (94) females. On average, each household comprised of five members of 3 males and 2 females. Majority of the respondents 50\% (100) were involved in farming activities within their farms, $25 \%$ (50) wereself employed, $20 \%$ (40) were in formal employment while only 5\% (10) were not employed (Table 5). Although there was observed difference in the number of respondents based on their occupation, it was not however statistically significant $(50 \pm 18.70 ; \mathrm{p}>0.5)$

\subsection{Level of Education}

Most of the respondents contacted had some level of education. It was found out that half of the respondents $50 \%$ (100) had attained tertiary level,13\% (30) had attained secondary school level 33\% (70)had attained primary level of education whileonly 4\% (10) had no any formal education (Figure 4).

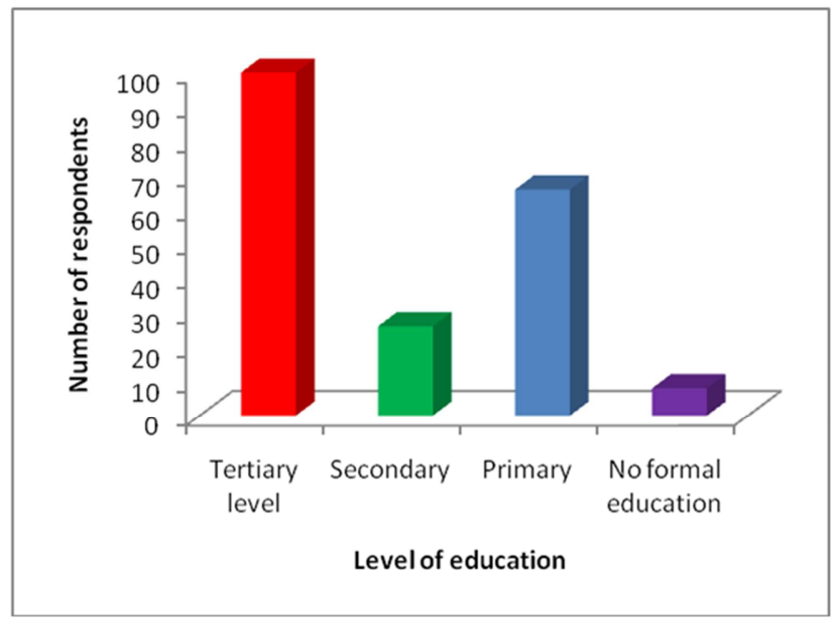

Figure 4. The level of education of the respondents

\subsection{Awareness of PELIS}

About 90\% (180) of respondents were conversant of the older name "Shamba system" while the rest had never heard of such a term. Moreover, out of the respondents who were aware of the shamba system, $66.67 \%$ of the respondents were aware of the PELIS programme as the current name from the old shamba system, while $33.33 \%$ were not aware (Figure 5).

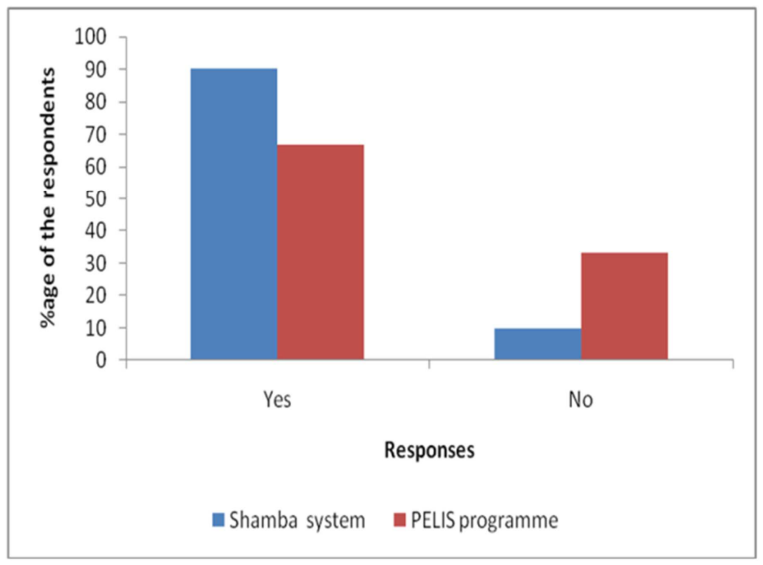

Figure 5. A comparison of the level of awareness of the shamba system and PELIS programme. 


\subsection{Land allocation}

On the size of the land allocated for the PELIS programme to the Forest Adjacent Communities (FAC), 63\% (134) admitted that they were allocated less than an acre while $37 \%$ (66) said that they were allocated between 1-2 acres. According to the respondents, land allocation was done based on the ability of the farmer to pay the land lease fee and renewal the next year. Whether theywere allowed to own more than one parcel of the allocated plot, 53\% said yes while $47 \%$ said no. Some respondents however felt that those who were given more than one parcel of lands wereas a result of corruption, tribalism and nepotism hence the programme has not been transparent. According to the respondents, majorly of them planted maize, beans and other short seasoned crops as one is expected to plant and harvest within a given period of time.Some of the trees planted in the programme were majorly Cypressus lusitanica and Pinus patula. Farmers were free to choose which crops to plant apart from long season crops.No livestock were allowed to graze on the plantations as it waslikely to destroy the planted trees. On whether the farmers were trained on PELIS programme, 93\% said that they have never trained.Only $7 \%$ especially the Community Forest Association (CFA) officialsagreed to have undergone some training.

\subsection{Improved Livelihoods}

Asked whether the programme helped improve livelihoods, $33 \%$ of the respondents stated that they received between Ksh 5,000 - 10,000 (47.62-95.24USD) while 30\% allocated more than one parcel of lands admitted to get over Kshs. 15,000 (142.83USD). About 6\% got between Kshs. 10,00015,000 (95.24-142.83 USD) while $17 \%$ especially those who got only one parcel of land did admittedto get less than Kshs. 5,000 (45.62 USD) annually (Figure 6).

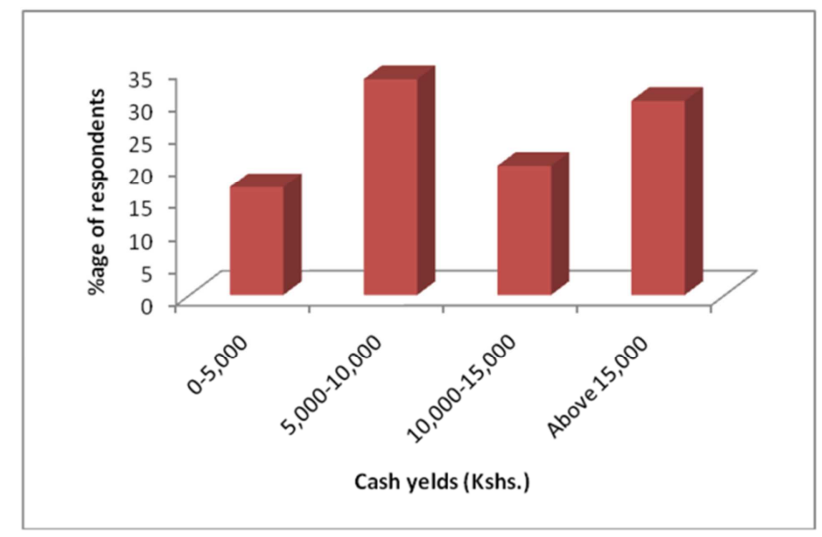

Figure 6. Cash yield from the PELIS programme farmers.

\subsection{Reduced Forest Dependency}

A total of $90 \%$ (180) of the respondents admitted that indeed the income and diversification on the forest lands has greatly reduced cases of the Forest Adjacent Communities (FAC) accessing forest for forest products for sale andthus has helped improve livelihoods. Only 10\% (20) did not agree that the programme has greatly helped reduce forest access by the communities (Figure 7).

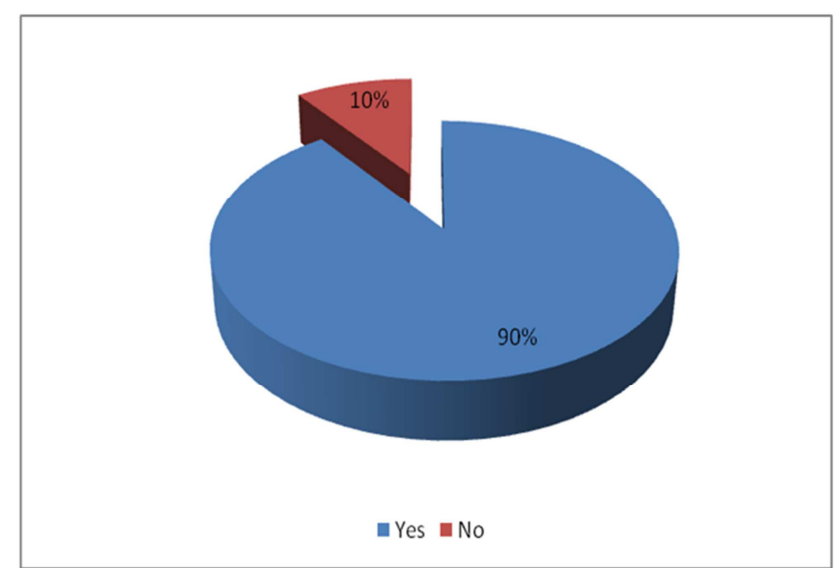

Figure 7. Forest dependency due to the introduction of the PELIS programme.

Majority of the respondents noted that despite the success of the programme, a number of challenges were still facedbut if well addressed would help improve more the livelihoods of people and increase forest cover. Among the challenges pointed out included: Corruption during allocation of plots, illegal grazing by farmers which destroys crops, theft of crops, destruction by wild animals particularly monkey, restricted movement of carts and lorries inside the forest hence a problem on transporting harvests from the middle of the forest. Others challenges included poor road conditions especiallyduring rainy season, encroachment to unauthorized areas and internal conflicts.

\section{Discussions}

In 2001, the forest cover was low as compared to 2016 (Figure 2). This could have been attributed to mismanagement of the PELIS programme formerly known as shamba system. The ban initially by the government slowed down restoration progress and vast areas of land under cultivation[16, 17]. Increased population around the forest and the need for more space for development for instance expansion of the schools around greatly contributed to the low forest cover as compared to 2016. Its re-introduction in 2007 could have resulted to progressive increase in forest cover as in 2016 in addition to natural recovery within the degraded areas.This research agrees with other studies done around Kakamega forest e.g[13] and [18] on possible causes of increased forest cover. The increase in forest cover was as a result of the PELIS programme. The programme increased area under PELIS countrywide from 2933ha in 2010 to 9939ha in 2013[19]. It was evident that indeed most of the forest adjacent communities around Malava Forest are conversant with the Shamba system as compared to the improved system of the same by the name PELIS programme. The number of people who are not conversant with the term could be attributed to lack of sensitization and capacity building by the Kenya Forest Service (KFS) in conjunction 
with the Community Forest Associations (CFAs). It could also be those who had no formal education or had attained only primary education.According to [16], lack of enough information and sensitization instead hindered effective implementation and thereafter its success. There is need for strengthening of institution that can provide capacity building that will ensure its effective success. The programme according to the KFS officials began in 2012 in Malava forest and has covered 116 hectares of land which has benefited approximately 240 households around the forest. According to [19], PELIS programme is one of the initiatives that Kenya Forest Service (KFS) has adopted as a restoration programme of the Kenya's forest resources. Land allocation for the programme is not done in a transparent manner as it has some allegations of corruption, nepotism to extend that outsiders are getting the parcel of lands from those in-charge of distributing the plots to the Forest Adjacent communities (FAC). For effectiveness of the programme and transparency in the distribution, it should be pegged on membership to the Community Forest Associations (CFAs) and the committee set up to oversee allocation must be fair enough to the members. According to $[2,11,1]$, members of the Community Forest Associations (CFAs) are the ones legally accepted to co-manage the forest resources in Kenya Cypressus lusitanica and Pinus patula were preferred trees for restoration as they are fast growers trees and can easily be managed by all the farmers irrespective of the level of education[20]. Farmers are allowed to do weeding of the trees and to do pruning and pollarding as practices that will hasten tree growth. However, these practices are practiced upon issuance of a permit by the Kenya Forest Service (KFS) The weeding of trees and care of the seedlings ensure high survival rate and hence assured of maturity. This also helps reduce cost on the side of KFS that would have employed casuals to do the weeding. From the findings, it is evident that the programme has greatly helped improve the farmers' income generating activities as some additional money is being realised from the programme. The additional income is what is mostly being used in the diversification of farming activities and incorporation of other money generating activities by the farmers. This agrees to similar studies done in other forests on how the programme has helped improve the forest adjacent community (FAC) livelihoods. For instance studies by $[19,11,17]$. The programme according to the respondents and the additional income indeed has helped reduce forest dependency as food security has improved at the same time firewood and other factors that can lead to reforest encroachment have been catered for with the introduction of the programme in the region. These are the changes that have been brought after the enactment of the Forest Act, 2005. The brought a number of reforms within the forest sector. The reforms were aimed at changing forest governance and at the same time help increase forest cover to a minimum of $10 \%$ as outlined in the Constitution of Kenya, 2010 [9,2,11]. PELIS programme which is aimed at empowering the local communities has had an impact to the forest adjacent communities and at the same time to the
Kenya Forest Service (KFS). This is due to the fact that it has reduced conflicts on access and utilisation of forest products through decreased forest dependency [17]. According to [21], reduced dependency on forests will help make forests have good quality stand in terms of stocking rate, straight boles and few weeds. Benefits farmers attributed get as a result of the programme included: Improved food security as a result of the food produce they get from the farms, provision of household needs like fee payment upon sale of produce, given extra seedlings during tree planting on forest, fodder during harvest season, poles for construction and firewood (snags and dry detached leaves), offered employment to the youth, and reduced grazing on the forest lands.

\section{Conclusions and Recommendations}

PELIS programme has had a success around Malava Forest, a fragment of Kakamega Forest. The programme had greatly helped reduce forest dependency, hence reduction in forest disturbance. This has resulted to gradual increase in forest cover. It has improved the livelihoods of the communities through increased and varied food supplies of maize, beans, potatoes, carrots and kales as well as assuring them of adequate food supply all year-round and increased income generation from sale of surplus harvest seedlings during tree planting in the nearby markets. It also offered employment to the youth and reduced grazing onto the forest lands. However, to ensure equality in distribution of the parcels of land, cases of corruption, favourism and tribalism have to be addressed so that only persons who are members of CFAs benefit. Training in entrepreneurship and organization capacity assessments can be carried out to increase their capacity in identifying profitable markets, storage and value addition. The governmentneeds to consider the issue of cost/benefit sharing to ensure that farmers continue with a the same portions to allow for provision of paid labour for forest thinning and harvesting revenues after the three year period. The government can also assist the PELIS farmers by providing alternative market outlets for their excess harvest, improving the road network and supporting other community projects.

\section{Acknowledgements}

We wish to sincerely thank Kenya Forest Service officers in charge of Malava forest for giving us some information relevant for the study. The chairman Malava community forest Association for helping us identify members who have benefited from PELIS. Lastly, the authors acknowledge members of the association who helped us get the information required while conducting the research.

\section{References}

[1] Kimutai, D.K. and Watanabe, T. (2016). Forest-Cover Change and Participatory Forest Management of the Lembus Forest, Kenya. Environments 3:20 
[2] Agevi, H., Wabusya, M. and Tsingalia, HM. (2014) Community Forest Associations and Community-Based Organizations: Redesigning their Roles in Forest Management and Conservation in Kenya. International Journal of Science andResearch (IJSR). 3(9) www.ijsr.net

[3] GOK, (2014). Forest Policy. Government of Kenya Printers, Nairobi, Kenya.

[4] Chao, S. (2012). Forest Peoples: Numbers Across the World; Forest Peoples Programme: Moreton-in-Marsh, UK.

[5] Maraga J. N., Kibwage J. K. and Oindo B. O. (2010). Factors determining community participation in afforestation projects in River Nyando basin, Kenya. African Journal of Environmental Science and Technology 4 (12): 853 - 859.

[6] Guthiga, P. and Mburu, J., (2006). Local communities incentives for forest Conservation: case of Kakamega Forest in Kenya. Paper presented at $11^{\text {th }}$ Biannual Conference of International Association for the Study of Common Property (IASCP), Indonesia.

[7] Food and Agricultural Organization of the United Nation (FAO). (2012). State of the World's Forest; FAO: Rome, Italy.

[8] Food and Agricultural Organization of the United Nation (FAO). (2010). Global Forest Assessment; FAO: Rome, Italy.

[9] GOK,(2005). Forest Act. Nairobi; Kenya: Government Printers.

[10] GOK,(2007), Plantation Establishment for Livelihood improvement scheme guidelines. Nairobi; Kenya: Government Printers.

[11] Gichuru, I. I. (2015). Factors contributing to the success of Pelis strategy in forest plantation establishment: Case study of Mucheene forest. International Academic Journal of Social Sciences and Education, 1 (4), 15-43.

[12] Agevi, H. (2012). Effects of canopy tree remnants in seedling germination and establishment in degraded areas of Kakamega Forest, Kenya. Msc thesis, Masinde Muliro University of Science and Technology (MMUST), Kenya.
[13] Althof, A., (2005). Human impact on flora and vegetation of Kakamega Forest, Kenya: Structure, distribution and disturbance of plant communities in an East African rainforest. $\mathrm{PhD}$ dissertation University of Koblenz-Landau, Germany.

[14] Kothari, C.R.(2003), Research Methodology: Methods and Techniques pp.68-69. New Delhi. New Age International Publishers.

[15] Congalton, R.G. (1991). A review of assessing the accuracy of classification of remotely sensed data. Remote sensing of environments 37 , No. 1,35-46.

[16] Kagombe J. K. and Gitonga J. M. (2005) Plantation Establishment in Kenya: The ShambaSystem Case Study.

[17] Ndomba, A.O. Bakengesa, S., Petro, R., Maguzu, J., Chamshama, S.A.O., Kiimu, H.R. and Lema, M.(2015). Perils of Taungya to the Productivity of Forest Plantations and Need for Modification: Case Study of Meru Forest Plantation in Tanzania.International Journal of Agriculture and Forestry 5(5): $267-275$.

[18] Kelly A. L., Kigen, C.K., Agevi, H. andKaleb, A.M. (2016) Trends in land use and land cover changes; drivers and impacts on Kakamega forest block.PROCEEDINGS of the conference on Expanding Theoretical and Applied Roles of GIS in a Dynamic Global Environment. MasindeMuliro University of Science and Technology. ISBN 978-9966-09654-8.Page 59-68.

[19] Kagombe, J.K. (2014). Contribution of Pelis towards increased tree cover and improved community livelihoods in Kenya. KEFRI, Nairobi, Kenya.

[20] Ogweno, D.O., M. Imo, A. Matano, and B.Orinda, (2001) Evaluation of the management and sustainability of private tree nurseries in Kipkaren River catchment, Kenya. $1^{\text {st }}$ National Scientific Conference, Lake Victoria Environmental Management Project, Kisumu, Kenya.

[21] Insaidoo, T. F. G., Acheampong E., and Ros-Tonen M. A. F. (2012) Management of Ghana's Modified Taungya System (MTS): Challenges and strategies for improvement. In IUFRO-FORNESSA Congress, Nairobi. 